\title{
Factors That Influence Consumers' Behaviors in Fashion Market
}

\author{
Xitong Xiang \\ Guangdong Experimental High School, Guangzhou, China \\ Email: xxt040208@163.com
}

How to cite this paper: Xiang, X. T. (2021) Factors That Influence Consumers' Behaviors in Fashion Market. Open Journal of Business and Management, 9, 2772-2779. https://doi.org/10.4236/ojbm.2021.96154

Received: September 29, 2021

Accepted: October 31, 2021

Published: November 3, 2021

Copyright (c) 2021 by author(s) and Scientific Research Publishing Inc. This work is licensed under the Creative Commons Attribution International License (CC BY 4.0).

http://creativecommons.org/licenses/by/4.0/ (c) (i) Open Access

\begin{abstract}
By describing the unique attributes of fashion market and comparing the fashion products with other products, this paper analyzes factors that contribute to consumers' behaviors in fashion market. Those factors include consumers' needs, social identity, and psychological irrationality. Particularly, I based my analysis on Maslow's theory of hierarchical needs, social identity theories, and human irrationality theories. The present article reviews these important factors and extends previous work by synthesizing the above-mentioned three aspects, which can provide basis for future studies on consumer behaviors in fashion market.
\end{abstract}

\section{Keywords}

Fashion Market, Consumer Behaviors, Need, Social Identity, Human Irrationality

\section{Introduction}

As many aspects of individuals' lives, such as education, internet, medical care, and so on, are boosting the global economy at a surprisingly fast pace, individuals' living standards are improving. People with stable income are paying more and more attention to their clothing, thus spurring fashion industry to flourish. For example, a recent report from Statista demonstrated that the revenue of global apparel market was 1802.59 billion dollars and it was estimated that it will achieve 2246.62 billion dollars worldwide by 2025 (Shahbandeh, 2021). To better serve the customers and achieve success in fashion businesses, it is necessary to investigate the factors that affect consumers' behaviors in fashion market.

Despite that consumers' behaviors in fashion market are controlled by time, money, and other variable factors, their self attributes and unconscious biases matter as well. Maslow's hierarchy needs function to influence consumers' pur- 
chasing intention from different dimensions, such as income disparities, gender disparities, and fast fashion. When social identity applies, people who belong to certain gender group or serve at certain positions are more likely to buy certain fashion items, so this is the reason that it is essential for the businesses to ensure their target customers. Moreover, consumers usually cannot realize the underlying biases they possess, which will affect the consumer choices unconsciously. Utilizing the customers' personal information and inevitable irrationality, businesses are able to create comprehensive marketing strategies to appeal to customers and maximize the profits. Thus, the present article analyzes factors that influence consumers' behaviors in fashion market and pointed to the implication of those factors in marketing strategies.

\section{Consumers' Needs}

Identifying consumers' needs are the first step for consumer purchase (Engel, Kollat, \& Blackwell, 1968). According to Maslow's theory of hierarchical need, five types of needs exist, from lowest order to highest order, including physiological need, safety and security needs, love and belonging needs, esteem needs, and self-actualization (Maslow, 1943). These needs are linked to individuals' behaviors in many scenarios, including socializing, working, as well as shopping, among which the purchasing behaviors worth investigating for it overthrows one of the economic postulates: people behave in rational ways and consider options and decisions within logical structure of thought (DiRita, 2014). The present article focuses on how consumers' needs affect their behaviors in fashion industry. Particularly, guided by Maslow hierarchy of needs theory, I investigated how income disparities, gender disparities, and money attitudes affect consumers' needs, thus influencing behaviors.

\subsection{Income Disparities}

Fashion industry plays a critical role as people's living standards are growing. The most significant features or representations in the fashion industry are apparel, footwear, and accessories. For people with low income and low social status, they cannot afford the apparel of famous brands, which means the purpose of purchasing clothes is merely to meet the physiological needs and security needs. For people with stable and high level of income, the basic needs are already satisfied, and they would shift their attention to luxury goods in order to meet their self-esteem needs, such as representing social status or gain more respect from others. According to Henry (2014), as income level increases, luxury items account for a greater share of the consumer's market basket. The data show that by year 2013 in Singapore, the first income quintile, which is the poorest quintile, spent only $1.8 \%$ of monthly expenditure on clothing and footwear, whereas the fifth income quintile spent about 2.7\% (The Singapore Department of Statistics, 2016). 


\subsection{Gender Disparities}

Another factor that shapes consumers' behaviors is gender disparities. For example, men and women differ when purchasing apparel. Specifically, men and women have distinct money attitudes, which reflect different levels of needs of men and women as well. As suggested by Oleson (2004), for men, money attitudes were most related to safety needs $(27.5 \%)$, whereas for women, money attitudes were most related to esteem needs (26.7\%). Therefore, women may pay more attention to and consider longer on which design model effectively shows their temperament and improves others' impression on themselves. Moreover, women were more likely to share attitudes of budget and retention than men.

Similarly, a recent study by Stuart (2019) further indicates gender difference in women and men's apparel purchasing. For instance, women are more engaged in apparel purchasing than men. First, "price" was an important factor to $70 \%$ of women shoppers, compared to $55 \%$ of men shoppers. Second, some $67 \%$ of women thought that "fits well" was important to their clothing purchasing, compared to $56 \%$ of male shoppers. Third, some $60 \%$ of women shoppers thought that apparel that "looks good" was important, while only $47 \%$ of male picked it as a factor.

\subsection{Fast Fashion}

The term "fast fashion" refers to the fashion trend that features a series of highstreet clothes inspired by the celebrities or from catwalks (Rauturier, 2021). The reason why fast fashion can secure a place in fashion market is because of people's intention or need to be accepted by the society, as referred to as Maslow' need of love and belonging. As some people around us start to wear a certain fashion item, people tend to integrate into the group by buying same or similar piece of fashion item. For example, bike shorts, initially wore by some celebrities and prevailing in the USA, spread to China in 2019 although they are common skinny pants wore by cyclists.

In conclusion, individuals purchase apparel or other luxuries basically for physiological needs, security needs, love and belonging needs, and self-esteem needs. However, individuals may differ in the degree they are influenced by those needs, depending on their gender, income, or other variables.

\section{Social Identity}

Maslow's hierarchy of need emphasizes individuals based on their personal identities. However, life is not a monodrama but full of connections with the society, which means people serve different roles in various social groups. This selfconcept of own role within a group is called social identity (McLeod, 2019). Social identity theory suggests that people define themselves based on social aspects, including perceptions of belonging to a human group (Tajfel, 1981). Tajfel defined social identity as "that part of an individuals' self-concept, which derives from his knowledge of his membership of a social group (or groups) together 
with the value and emotional significance attached to that membership". In other words, people take different responsibilities corresponding to different social identities. In return, social identities influence individuals' attitudes and behaviors in various aspects in their lives, consuming behaviors in particular. Below I examined how different social identities affect consumers' behaviors in fashion market.

\subsection{Gender}

One of the most common social identities is gender. According to the research, women's possibility to purchase an item in all segments in fashion market except accessories was nine percent higher than men (Stuart, 2019). Although women themselves are more engaged in shopping than men, their different identities matter as well. Other than being a woman, she may also be a mother and a daughter, which makes them purchase clothes for their children and the elderly more commonly than men do (Stuart, 2019). Conceivably, some arguments state that women are overwhelmed by taking care of their children all day long and have limited time to shop, so the housewives have little contribution to the purchasing power of women. However, as the internet technology as well as the online shopping platforms gradually penetrates our daily lives, people, especially women, have more access to shopping. Considering the fact that online shopping provides consumers more choices of brands and products and requires less cost, including commuter costs, time costs, and so forth, the youths are inclined to purchase online and the online fashion markets are developing rapidly. As suggested by Orendorff (2021), online fashion industry market value will rise from $\$ 759.5$ billion in 2021 to over $\$ 1.0$ trillion by 2025. Therefore, women are still considered the majority leading this trend of online shopping.

\subsection{Occupation}

Occupation is another typical social identity, through which individuals are able to fulfill self-values and exploit their potentials, thereby contributing to the society. Working in different positions, people may focus on different attributes of goods before making purchasing decisions. Perhaps it is the natures of their jobs that require them to dress up in certain style or people just favor. In turn, consistent exposure to certain working environment nurtures one's apparel style and the way they want to reveal themselves.

People working in service industry stress the "uniqueness value" "hedonic value" "prestige value" more than the professionals and business people do by Srinivasan, Srivastava and Bhanot (2014). This is probably because service people, such as those working in tourist industry, medical industry or educational industry, have close contact with their customers, which unintentionally makes them to care about their personal images to leave a decent impression on the customers. Differ from the frequent cooperation among business people and professionals, the common relationship in service people's workplaces is providing 
service and receiving service, which renders them feel a kind of responsibility and uniqueness of this clear defining of roles. In this case, the unique designs of the fashion products are more likely to attract customers from service industry.

Moreover, business people value more on "usability" than service people and professionals do (Srinivasan, Srivastava, \& Bhanot, 2014). This tendency can be attributed to the business thinking developed throughout their careers. Business people may consider whether the product is cost-effective by focusing on the quality or usability to make purchasing decisions. For example, the durability or the suitability may serve as factors of determining the usability of fashion products, and the appropriateness of the products used in certain situation influences their decisions as well. Hence, occupations affect customers' purchasing decisions in some ways, and people working in different positions may pay attention to certain attributes to different extent.

\section{Irrationality}

Many economic models and theories were built based on the assumption of "Homo Economicus" or "economic man", which postulates that human beings are rational when making decisions by using limited resources to maximize their own benefits (Smith, 1776). However, this idealized situation never exists because of the susceptibility of human nature and people always hold biases and irrationality when making decision, which happens unconsciously and inevitably. These biases and irrationality strongly influence purchasing behaviors in particular for people are making choices all the time when being consumers. Here in the present article, I focused on the anchoring effect, the halo effect, and availability heuristic that are more obvious and have greater influence on consuming behaviors in fashion market.

\subsection{Anchoring Effect}

Tversky and Kahneman (1974) introduced that anchoring effect is that people make decisions or judge something based on the initial piece of informationthe anchor-they obtain. This psychological bias can be seen in many facets of our lives, such as the consuming behaviors. For example, the initial price consumers know serves as the anchor or standard when they decide whether to buy the product or not at the current price. Although the anchoring bias affects consuming behaviors of all goods to some extents, consumers are more susceptible of this effect when purchasing in fashion market. Different from daily necessities of what we eat or use, fashion products like apparels, accessories and shoes are generally more expensive, so most individuals will consider whether to buy depending on the previous price they know to avoid spending too much. Moreover, the demand of products from fashion market is not as urgent as that of other products, so consumers are inclined to buy them at an economic price, which means they are likely to compare the current price with early known price. However, daily necessities occupy a much larger market and consumers must be 
loyal to certain brands. Considering the price, quality and their adaptivity, consumers will decisively continue to purchase the products of preferred brands even if the price increases. According to the research about the anchoring effect on purchase intention of organic food (Shan, Diao, \& Wu, 2020), consumers will have high purchase intention and positive attitude towards the organic food when presented with lower anchor price. The reason is that people are not familiar with organic food and tend to compare the price of it to non-organic food. If the anchor price is high and the price gap between organic food and non-organic food is large, people will feel they were deceived and are less likely to purchase the organic food. Therefore, it is reasonable to speculate that when consumers in fashion market face unfamiliar brands, a relatively low anchor price for that brand may boost their purchase intention.

\subsection{Halo Effect}

The halo effect means that one single trait of an item, an event or a person will influence individuals' impression on its other unrelated traits (Thorndike, 1920). In fashion market, people can either consume in offline stores or online stores. Generally speaking, the extent to which halo effect influences consumers' behaviors depended on the popularity of the brands, which means consumers may favor and are more likely to purchase those well-known brands instead of less well-known brands (Beckwith, Kassarjian, \& Lehmann, 1978). If individuals intend to try some new and lesser-known brands, the first thing they notice is the design of the store or the website, which is the key to appealing to the customers. Influenced by the halo effect, people tend to prefer buying in those stores with delicate appearance and designs because they believe the products in these stores will be in high quality as well. By contrast, small stores with simple and normal designs signify that the products are in low cost and low quality, thus reducing people's desire to consume. Moreover, Koltuv (1962) stated that the halo effect strengthens as familiarity decreases, which is applicable to the situation in fashion market as well. When facing unfamiliar products, if consumers feel satisfied about the price and quality of one piece of fashion item they bought, they are likely to regard other types of products of that brand as equally worth buying, thereby boosting consumption again and again. For instance, after a woman bought a dress in one store which was comfortable and also cost-effective, she would be likely to purchase a pair of shoes in the same store for she believed that pair of shoes was also comfortable to wear even though she was completely unfamiliar with the brand. This is how the halo effect works to attract customers and stimulate them to purchase.

\section{Conclusion}

Considering consumers' needs and social identity, businesses are supposed to do surveys to collect information about people's fashion favors and ensure their target customers. To make the fashion brands prosper continuously in the long 
run and better utilize these psychological biases, the core principle is to improve the quality as much as possible. Reputation of most famous fashion brands is built upon the quality of the products, such as luxury handbag brands like Hermès, Louis Vuitton, Channel, and jewelry brands like Pandora and Tiffany \& Co. Once the quality improves, people who are unfamiliar with the brand will be exposed to it through the words of mouth, thus increasing the probability of availability heuristics.

\section{Conflicts of Interest}

The author declares no conflicts of interest regarding the publication of this paper.

\section{References}

Beckwith, N. E., Kassarjian, H. H., \& Lehmann, D. R. (1978). Halo Effects in Marketing Research: Review and Prognosis. The Association for Consumer Research. https://www.acrwebsite.org/volumes/9466/volumes/v05/NA

DiRita P. (2014). Economic Rationality Assumption. In A. C. Michalos (Eds.) Encyclopedia of Quality of Life and Well-Being Research. Springer, Dordrecht. https://doi.org/10.1007/978-94-007-0753-5 822

Engel, J. F., Kollat, D. T., \& Blackwell, R. D. (1968). Consumer Behaviour. Holt, Rinehart and Winston, Inc.

Henry, L. M. (2014). Income Inequality and Income-Class Consumption Patterns. Economic Commentary (Federal Reserve Bank of Cleveland), 1-4. https://doi.org/10.26509/frbc-ec-201418

Koltuv, B. B. (1962). Some Characteristics of Intrajudge Trait Intercorrelations. Psychological Monographs: General and Applied, 76, 1-33. https://doi.org/10.1037/h0093859

Maslow, A. H. (1943). A Theory of Human Motivation. Psychological Review, 50, 370-396. https://doi.org/10.1037/h0054346

Mcleod, S. (2019, October 24). Social Identity Theory. Simply Psychology. https://www.simplypsychology.org/social-identity-theory.html

Oleson, M. (2004). Exploring the Relationship between Money Attitudes and Maslow's Hierarchy of Needs. International Journal of Consumer Studies, 28, 83-92.

https://doi.org/10.1111/j.1470-6431.2004.00338.x

Orendorff, A. (2021, March 16). 10 Trends Styling 2021â s Ecommerce Fashion Industry: Growth + Data in Online Apparel \& Accessories Market. Common Thread Collective. https://commonthreadco.com/blogs/coachs-corner/fashion-ecommerce-industry-trend $\underline{s}$

Rauturier, S. (2021, July 26). What Is Fast Fashion? Good on You. https://goodonyou.eco/what-is-fast-fashion/

Shahbandeh, M. (2021, January 21). Global Revenue of the Apparel Market, 2012-2025. Statista. https://www.statista.com/forecasts/821415/value-of-the-global-apparel-market

Shan, L., Diao, H., \& Wu, L. (2020). Influence of the Framing Effect, Anchoring Effect, and Knowledge on Consumers' Attitude and Purchase Intention of Organic Food. Frontiers in Psychology, 11, Article No. 2022. https://doi.org/10.3389/fpsyg.2020.02022 https://www.frontiersin.org/articles/10.3389/fpsyg.2020.02022/full

Smith, A. (1776). An Inquiry into The Nature and Causes of The Wealth of Nations: Com- 
plete Five Unabridged Books (Illustrated ed.). Chump Change. https://doi.org/10.1093/oseo/instance.00043218

Srinivasan, D. R., Srivastava, D. R. K., \& Bhanot, P. (2014). Impact of Education on Purchase Behaviour of Luxury Brands. IOSR Journal of Business and Management, 16, 63-74. https://doi.org/10.9790/487X-161116374

Stuart, O. (2019, October 1). How Do Men \& Women Shop for Clothes Differently? Freedonia Focus Reports.

https://www.freedoniafocusreports.com/Content/Blog/2019/10/01/How-Do-Men--Wo men-Shop-for-Clothes-Differently

Tajfel, H. (1981). Human Groups and Social Categories-Studies in Social Psychology. Cambridge University Press.

The Singapore Department of Statistics (2016, August 2). Distribution of Monthly Household Expenditure by Type of Goods and Services (Detailed) and Income Quintile. Data.gov.sg.

https://data.gov.sg/dataset/distribution-monthly-household-expenditure-type-goods-se rvic-

es-detailed-income-quintile?view id=53a708f5-c70a-498d-9653-76cd7f395dcd\&resour ce id=6d3087a6-a040-452f-alee-cf27ba81a98f

Thorndike, E. L. (1920). A Constant Error in Psychological Ratings. Journal of Applied Psychology, 4, 25-29. https://doi.org/10.1037/h0071663

Tversky, A., \& Kahneman, D. (1974). Judgment under Uncertainty: Heuristics and Biases. Science, 185, 1124-1131. https://doi.org/10.1126/science.185.4157.1124 